\title{
In reply to the letter to the editor regarding "The efficacy and safety of tranexamic acid in high tibial osteotomy: a systematic review and meta-analysis"
}

\author{
Jimin $\mathrm{Ma}^{1}$, Hanli Lu ${ }^{2}$ Xinxing Chen ${ }^{2}$, Dasai Wang ${ }^{2}$ and Qiang Wang ${ }^{2 *}$
}

Keywords: Blood loss, Hemoglobin decrease, Drain output, High tibial osteotomy, Tranexamic acid, Meta-analysis

\section{Dear Editor,}

We appreciate all of the reviewers for their thought-provoking comments about our recent meta-analysis published in the journal [1]. Our answers to these questions raised are as follows:

Firstly, although the heterogeneity of total blood loss is high, we use the random effects model that allows reliable pooled results; this heterogeneity might be attributed to different surgical procedures. At present, there is no conclusion about the data-base to be searched. Many meta-analyses also searched only two or three databases [2-11]. The three databases we searched (PubMed, Embase and Cochrane Library) can find most of the literatures. The article on Ma [12] cannot be included in the above three databases. Also, it was published later than our deadline for retrieval.

It is well known that the prevalence of knee osteoarthritis is much higher in female. Meta-regression analysis for gender as an item does not make much sense. We do not think it is appropriate to conclude that female might benefit more than male on blood management from tranexamic acid (TXA) by dividing them into three subgroups based on gender. From their results, it can only be

*Correspondence: 13909636163@126.com

2 Department of Orthopedics, Yijishan Hospital of Wannan Medical College, Wuhu, Anhui, China

Full list of author information is available at the end of the article concluded that no matter what the proportion of female is, TXA can benefit. Moreover, gender difference could affect total blood loss, with greater amount in men compared with women [13-15].

Secondly, we agree with the hypothesis that intraoperative TXA had a short-time effect, but it might benefit patients for a relatively long time. This is consistent with the results of our meta-analysis, which is also in agreement with previous studies [16, 17].

Finally, most of the studies included in this meta-analysis are cohort studies, which cannot be as consistent as randomized controlled trials (RCTs). And we choose random-effect model to make the results tend to be conservative. Moreover, the results were consistent even with the fixed-effect model (Figs. 1 and 2). The Stata 15.0 software (StataCorp, College Station, TX, USA) was performed to evaluate the publication bias. The results of the funnel plot "Egger test" $(P=0.247)$ indicated a low risk of publication bias. However, as this meta-analysis did not include enough studies, the reliability of these assessments was not very strong. Strictly speaking, publication bias in this study is not necessary.

\section{Abbreviations}

TXA: Tranexamic acid; RCTs: Randomized controlled trials.

\section{Acknowledgements}

None.

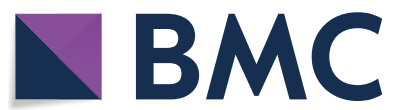

(c) The Author(s) 2021. Open Access This article is licensed under a Creative Commons Attribution 4.0 International License, which permits use, sharing, adaptation, distribution and reproduction in any medium or format, as long as you give appropriate credit to the original author(s) and the source, provide a link to the Creative Commons licence, and indicate if changes were made. The images or other third party material in this article are included in the article's Creative Commons licence, unless indicated otherwise in a credit line to the material. If material is not included in the article's Creative Commons licence and your intended use is not permitted by statutory regulation or exceeds the permitted use, you will need to obtain permission directly from the copyright holder. To view a copy of this licence, visit http://creativecommons.org/licenses/by/4.0/. The Creative Commons Public Domain Dedication waiver (http://creativeco mmons.org/publicdomain/zero/1.0/) applies to the data made available in this article, unless otherwise stated in a credit line to the data. 


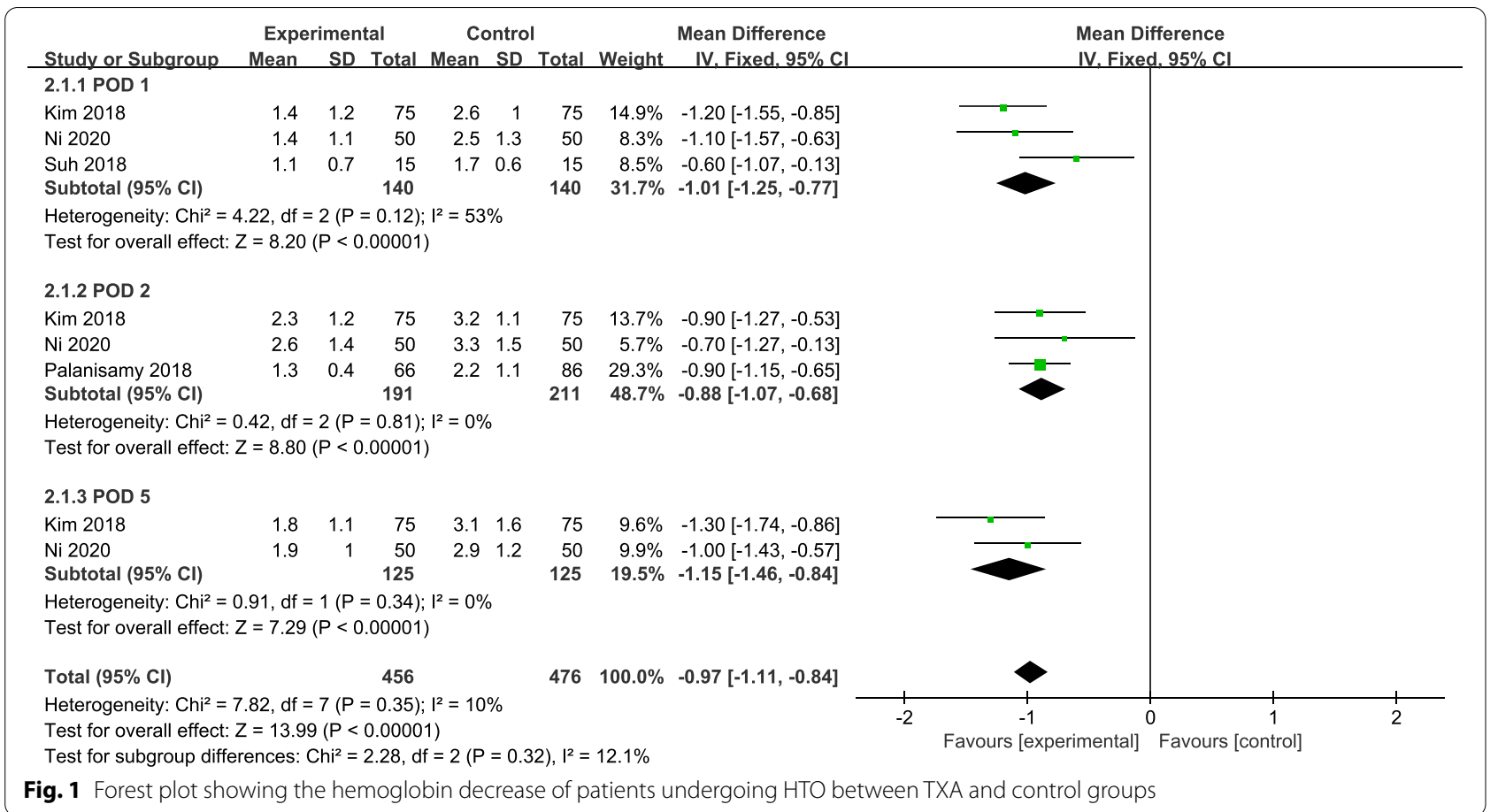

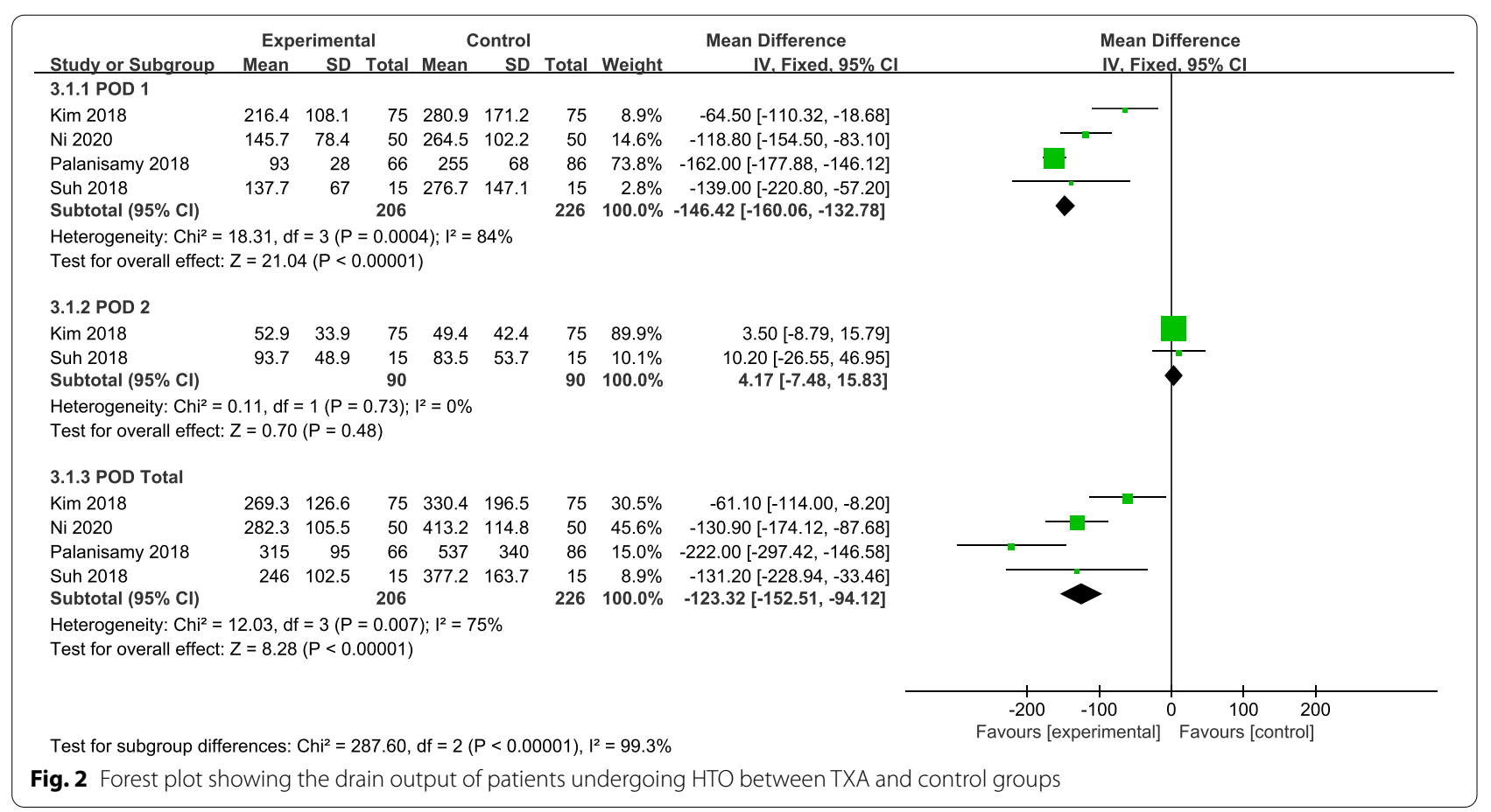

\section{Authors' contributions}

$J M-M$ analyzed the data and was a major contributor in writing the manuscript; HL-L was a contributor in the data analysis; XX-C and DS-W were contributors in writing the manuscript; Q-W was responsible for reviewing and editing the manuscript. The authors read and approved the final manuscript.

\section{Authors' information}

Mr. Jimin Ma, the first author of this article, was a graduate student in the Department of Orthopedics, Yijishan Hospital, at the time of publication. He graduated on June 30 and is working in the Department of Orthopedics, Fuyang Hospital of Anhui Medical University. The unit has been updated for this. 


\section{Funding}

This study was supported by the Key Project of University Humanities and Social Science Research in Anhui Province (SK2016A0963).

\section{Availability of data and materials}

All data generated or analyzed during this study are included in this published article.

\section{Declarations}

Ethics approval and consent to participate

Not applicable.

\section{Consent for publication}

Not applicable.

\section{Competing interests}

The authors declare that there are no conflicts of interest.

\section{Author details}

${ }^{1}$ Department of Orthopedics, Fuyang Hospital of Anhui Medical University, Fuyang, Anhui, China. ${ }^{2}$ Department of Orthopedics, Yijishan Hospital of Wannan Medical College, Wuhu, Anhui, China.

Received: 21 July 2021 Accepted: 23 July 2021

Published online: 16 August 2021

\section{References}

1. Ma J, Lu H, Chen X, Wang D, Wang Q. The efficacy and safety of tranexamic acid in high tibial osteotomy: a systematic review and metaanalysis. J Orthop Surg Res. 2021:16:373.

2. Gay F, Jackson G, Rosiñol L, Holstein SA, Moreau P, Spada S, Davies F, Lahuerta JJ, Leleu X, Bringhen S, Evangelista A, Hulin C, Panzani U, Cairns DA, Di Raimondo F, Macro M, Liberati AM, Pawlyn C, Offidani M, Spencer A, Hájek R, Terpos E, Morgan GJ, Bladé J, Sonneveld P, San-Miguel J, McCarthy PL, Ludwig H, Boccadoro M, Mateos MV, Attal M. Maintenance treatment and survival in patients with myeloma: a systematic review and network meta-analysis. JAMA Oncol. 2018;4:1389-97.

3. Boulos MI, Jairam T, Kendzerska T, Im J, Mekhael A, Murray BJ. Normal polysomnography parameters in healthy adults: a systematic review and meta-analysis. Lancet Respir Med. 2019;7:533-43.

4. Clarke MA, Long BJ, Del Mar MA, Arbyn M, Bakkum-Gamez JN, Wentzensen N. Association of endometrial cancer risk with postmenopausal bleeding in women: a systematic review and meta-analysis. JAMA Intern Med. 2018;178:1210-22.

5. Scott ML, Baldwin KD, Mistovich RJ. Operative versus nonoperative treatment of pediatric and adolescent clavicular fractures: a systematic review and critical analysis. JBJS Rev. 2019;7:e5.
6. Yaghmour KM, Hossain FS, Konan S. Clinical and health-care cost analysis of negative pressure dressing in primary and revisiontotal knee arthroplasty: a systematic review and meta-analysis. J Bone Joint Surg Am. 2020;103:541-8.

7. Bram JT, Magee LC, Mehta NN, Patel NM, Ganley TJ. Anterior cruciate ligament injury incidence in adolescent athletes: a systematic review and meta-analysis. Am J Sports Med. 2021;49:1962-72.

8. Chan XHS, Win YN, Mawer LJ, Tan JY, Brugada J, White NJ. Risk of sudden unexplained death after use of dihydroartemisinin-piperaquine for malaria: a systematic review and Bayesian meta-analysis. Lancet Infect Dis. 2018:18:913-23.

9. Ekelund U, Steene-Johannessen J, Brown WJ, Fagerland MW, Owen N, Powell KE, Bauman A, Lee IM. Does physical activity attenuate, or even eliminate, the detrimental association of sitting time with mortality? A harmonised meta-analysis of data from more than 1 million men and women. Lancet. 2016:388:1302-10.

10. Zheng Z, Luo J. The therapeutic effect to eldecalcitol + bisphosphonate is superior to bisphosphonate alone in the treatment of osteoporosis: a meta-analysis. J Orthop Surg Res. 2020;15:390.

11. Fan Y, Li Z, Zhang H, Hong G, Wu Z, Li W, Chen L, Wu Y, Wei Q, He W, Chen Z. Valgus knee bracing may have no long-term effect on pain improvement and functional activity in patients with knee osteoarthritis: a metaanalysis of randomized trials. J Orthop Surg Res. 2020;15:373.

12. Zhong ZMDLXWW. Safety evaluation of tranexamic acid in reducing perioperative blood loss in high tibial osteotomy. Chin J Tissue Eng Res. 2021;25:1847-52.

13. Guerin S, Collins C, Kapoor H, McClean I, Collins D. Blood transfusion requirement prediction in patients undergoing primary total hip and knee arthroplasty. Transfus Med. 2007;17:37-43.

14 Mähringer-Kunz A, Efe T, Fuchs-Winkelmann S, Schüttler KF, Paletta JR, Heyse TJ. Bleeding in TKA: posterior stabilized vs. cruciate retaining. Arch Orthop Trauma Surg. 2015;135:867-70

15. Hu Y, Li Q Wei BG, Zhang XS, Torsha TT, Xiao J, Shi ZJ. Blood loss of total knee arthroplasty in osteoarthritis: an analysis of influential factors. J Orthop Surg Res. 2018;13:325.

16. Kim Kl, Kim HJ, Kim GB, Bae SH. Tranexamic acid is effective for blood management in open-wedge high tibial osteotomy. Orthop Traumatol Surg Res. 2018;104:1003-7.

17 Ni J, Liu J, Zhang J, Jiang J, Dang X, Shi Z. Tranexamic acid is beneficial for blood management of high tibial osteotomy: a randomized controlled study. Arch Orthop Trauma Surg. 2020. https://doi.org/10.1007/ s00402-020-03558-5.

\section{Publisher's Note}

Springer Nature remains neutral with regard to jurisdictional claims in published maps and institutional affiliations.

Ready to submit your research? Choose BMC and benefit from

- fast, convenient online submission

- thorough peer review by experienced researchers in your field

- rapid publication on acceptance

- support for research data, including large and complex data types

- gold Open Access which fosters wider collaboration and increased citations

- maximum visibility for your research: over 100M website views per year

At BMC, research is always in progress.

Learn more biomedcentral.com/submissions 